\title{
HYDROGEOLOGICAL DYNAMIC VARIABILITY IN THE LOMME KARST SYSTEM (BELGIUM) AS EVIDENCED BY TRACER TESTS RESULTS (KARAG PROJECT)
}

\author{
Amaël Poulain \\ Department of Geology - University of Namur, Rue de Bruxelles, $n^{\circ} 61$, Namur, 5000, Belgium, \\ amael.poulain@unamur.be \\ Gaëtan Rochez \\ Department of Geology - University of Namur, Rue de Bruxelles, $n^{\circ} 61$, Namur, 5000, Belgium \\ Vincent Hallet \\ Department of Geology - University of Namur, Rue de Bruxelles, $n^{\circ} 61$, Namur, 5000, Belgium
}

\begin{abstract}
Paleozoic carbonate aquifers represent major groundwater resources in Belgium. Karstification processes affect most of them and Belgium counts many hydrologically active karst networks. Given the intrinsic vulnerability of such geology, comprehensive studies are required in order to improve their protection and management.
\end{abstract}

The KARAG project (Karst Aquifer ReseArch by Geophysic, 2013-2017) aims to identify the specific dynamic of karst aquifers by using geophysical and hydrogeological tools. This research is funded by the Belgium National Fund for Scientific Research (FNRS) and conducted by the University of Namur, University of Mons and the Royal Observatory of Belgium.

The LKS - Lomme Karst System (Rochefort, southern Belgium) was chosen as it is a major Belgian karst system (10 km long) in the Givetian carbonate aquifer (Middle Devonian). The system is formed by two parallel components: the surface system (the Lomme River) and a complex underground system (multiple sinkholes with one main resurgence). Based on this layout, it is possible to study the aquifer dynamic and its relationship with the surface river.

A high resolution monitoring network has been in place since July 2013 in order to follow the system dynamic during several hydrogeological cycles.

Multi-tracing experiments with different injections and monitoring points highlight the complexity of underground flow dynamics. Investigations enlightened the connectivity between monitoring points and how dependent of the hydrological conditions were these connections. The breakthrough curves analysis allows to characterize the hydrodynamic behavior of the underground flows within the aquifer.

Modeling will be necessary to link hydrological and tracer tests data in order to build a detailed conceptual model for this karst system. This model will also be used to interpret geophysical data (ERT, gravimetry) collected in order to study the unsaturated and epikarst zones.

\section{Introduction}

Karst areas represent an important part of the Belgian territory, especially in the south (Wallonia) where Paleozoic limestones (Carboniferous and Devonian) have extensive cave development. A report established in 2011 stated that groundwater coming from those limestones represents $53 \%$ of the total water volume extracted from Walloon aquifers (200 million cubic meters; SPW-DGO3, 2014). In addition, Belgium is a densely populated country with heavy agricultural and industrial development. Many human activities represent a threat for the karst media especially in terms of water quality.

There are several active karst systems in Wallonia and only a few of them are well understood. The recharge areas, the underground connections and the hydrological behavior regarding hydrological conditions are the main questions to be answered in order to protect those systems. It is clear that comprehensive studies about 
the behavior of karstic systems will help to improve the management of their water resources.

The KARAG project, launched in 2013, aims to understand the characteristics of epikarst and karst aquifers with a multidisciplinary approach: hydrogeology and geophysic (ERT and gravimetry). This 4-year study is funded by the National Fund for Scientific Research in Belgium (FNRS) and conducted by the University of Namur, University of Mons and the Royal Observatory of Belgium. The Lomme Karst System (LKS) was chosen as it is one of the main karst system in Belgium. One of the key work package concerns the hydrogeological behavior of the karst system that may be synthetized in three main questions:

- What is the hydrogeological organization of the karst system (flow connections)?

- What is the dynamic of those connections during variable hydrological conditions?

- What is the relationship between the subterranean karst system and the surface Lomme River?

This short paper introduces this particular research topic presenting our methodologies and first results.

\section{The Lomme Karst System (LKS)}

The LKS is located in south Belgium, near the city of Rochefort, within the Lomme River valley (Figure 1). It is one of the longest active karst systems in Belgium with almost $10 \mathrm{~km}$ of a complex underground network with multiple sinkholes and one main resurgence (Figures 3 and 4 ). The different cave networks are formed within

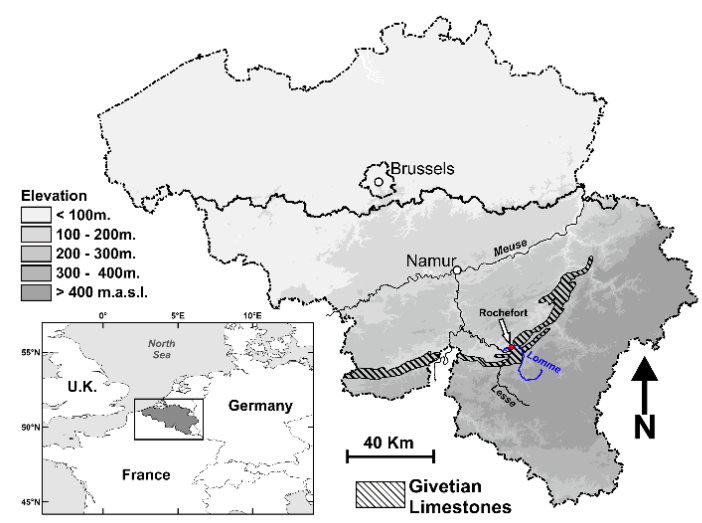

Figure 1. Location of Rochefort, the Lomme valley and the Givetian limestones in south Belgium. the Givetian carbonated aquifer (Middle Devonian), which is one of the most karstified aquifers in Belgium. At the surface, the Lomme River is flowing on the Givetian limestones, almost parallel to the underground network(s).

The first item interest in this system is the double (surface and subterranean) flow system which allows a comparison of the fate of water in both.

The general organization of the underground flow paths seems to be simple because all the water entering the karst system (through sinkholes or dolines) will flow to the Eprave resurgence (the biggest in Belgium with an average discharge of 800 liters/sec), the only final point of this karst network.

However, the dynamic of underground flows is very complicated because every sinkhole feeds different subterranean rivers. The relationships between those rivers is not yet fully understood.

The large number of caves with hydrogeological features (15) provides a great opportunity to understand the functioning of this system. Moreover, recent speleological discoveries bring new information about underground rivers in this karst system.

\section{Methodology}

In order to collect enough data to feed our future hydrogeological model, 20 water probes were installed throughout the LKS and in the surrounding karst aquifer and surface rivers (Figures 3 and 4). A 15-minute time interval will provide high resolution data (water level, temperature and electrical conductivity) to understand

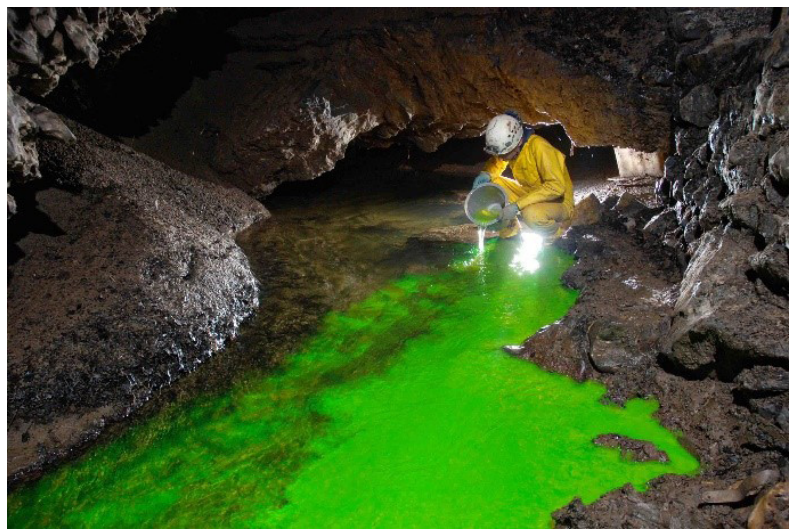

Figure 2. Uranine injection in the Lorette cave river during low water conditions. 


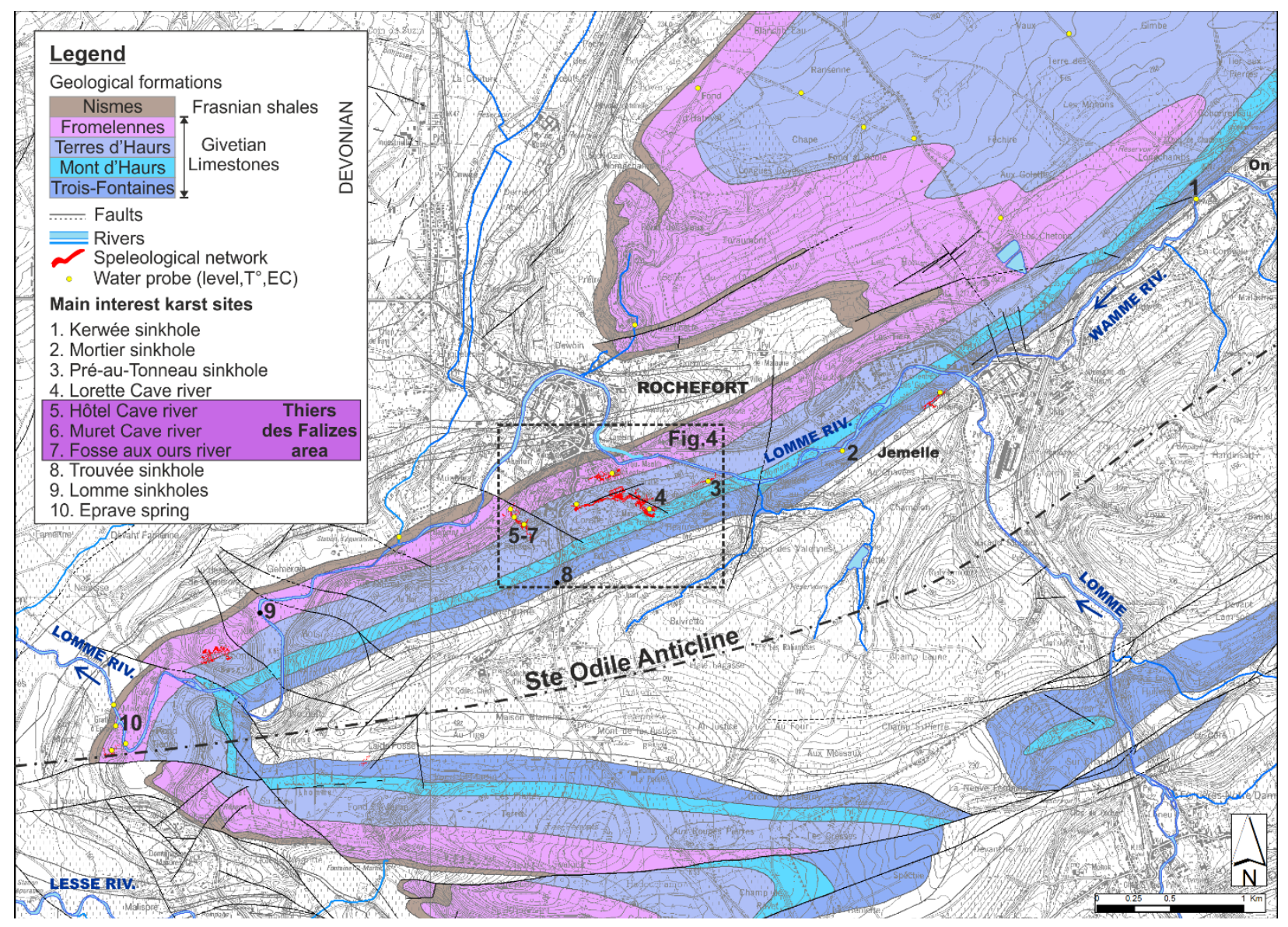

Figure 3. Geological map of the Lomme karst System with the main Givetian limestone formations, speleological networks, water probes and main interest karst sites for the hydrogeological study and tracer test experiments (geological background: Barchy et al. submitted; Blockmans and Dumoulin, submitted).

the system dynamics during various hydrogeological cycles. Treatment and analysis of piezometric data will be done in a future step of the project.

The main part of the hydrogeological study is devoted to dye tracing. In 2014, five GGUN-FL30 fluorometers (Schnegg, 2002) were used to conduct tracer tests in varying hydrologic conditions. Uranine $\left(\mathrm{C}_{20} \mathrm{H}_{10} \mathrm{Na}_{2} \mathrm{O}_{5}\right)$ and sulforhodamine $\mathrm{B}\left(\mathrm{C}_{27} \mathrm{H}_{30} \mathrm{~N}_{2} \mathrm{O}_{7} \mathrm{~S}_{2}\right)$ were used for injections performed at various injection locations. Two dye tracing campaigns were conducted: in February (high water conditions) and in September (low water conditions).

Different sites were chosen for a total of 9 tracer injections during the two campaigns (Figures 3 and 4):

- The Kerwée sinkhole, on the Wamme river (point 1);

- The Mortier sinkhole, on the Lomme river (point 2);

- The Pré-au-Tonneau sinkhole, on the Lomme river (point 3);

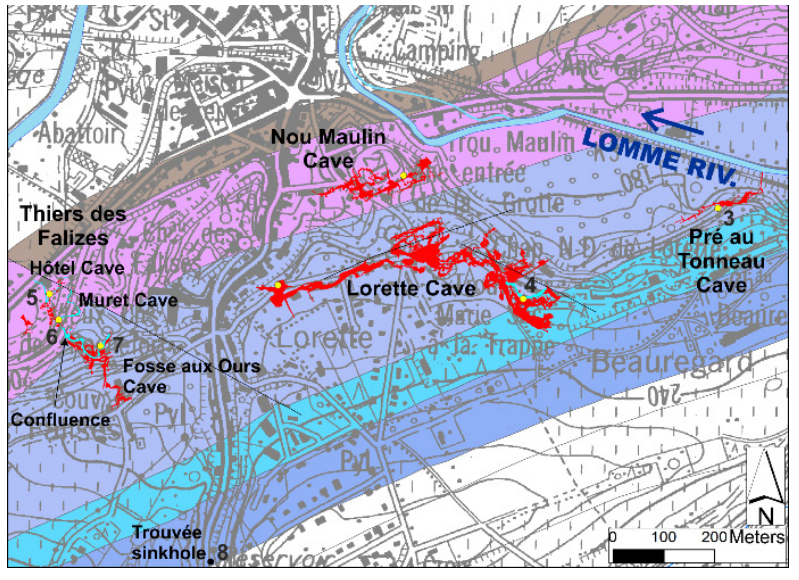

Figure 4. Zoom of Figure 3 showing the caves and interest points at the south of the city of Rochefort; Yellow points represent water probe locations, numbers refer to the Figure 3 list. 


\section{Period 1 : High water conditions (February 2014)}
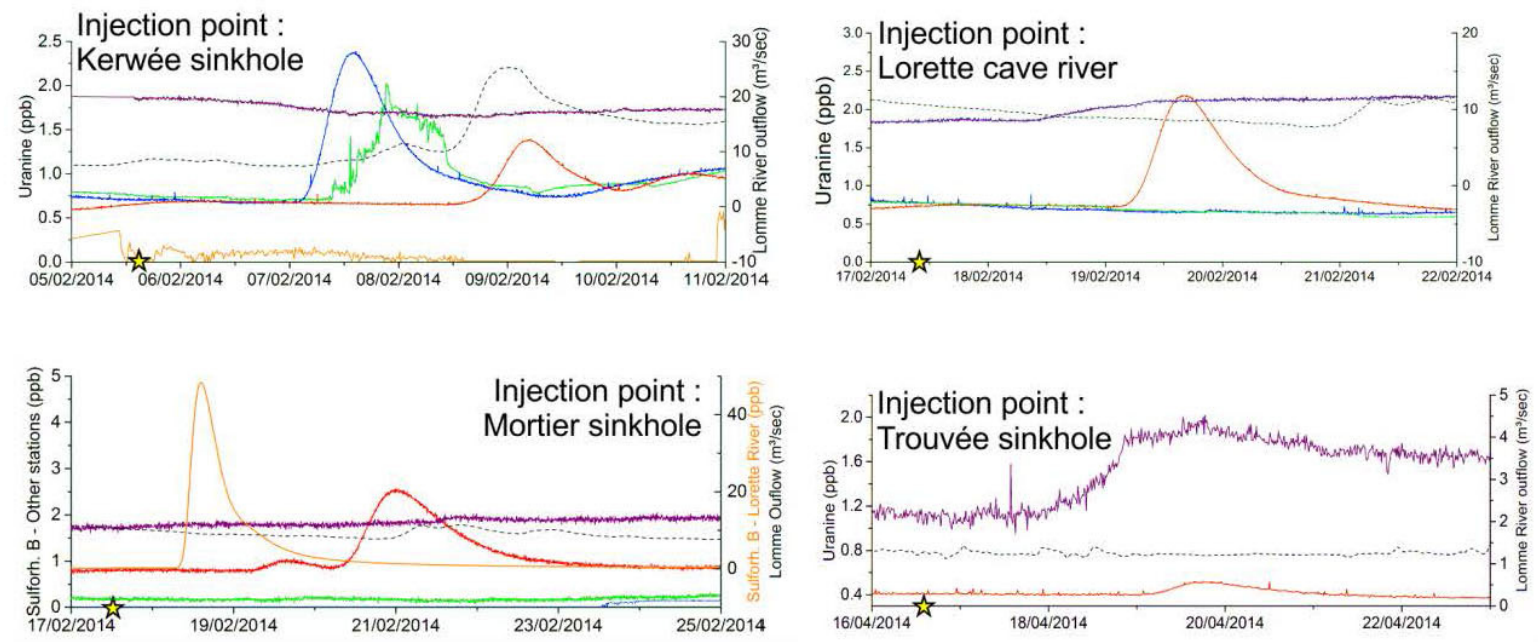

\section{Period 2 : Low water conditions (September 2014)}
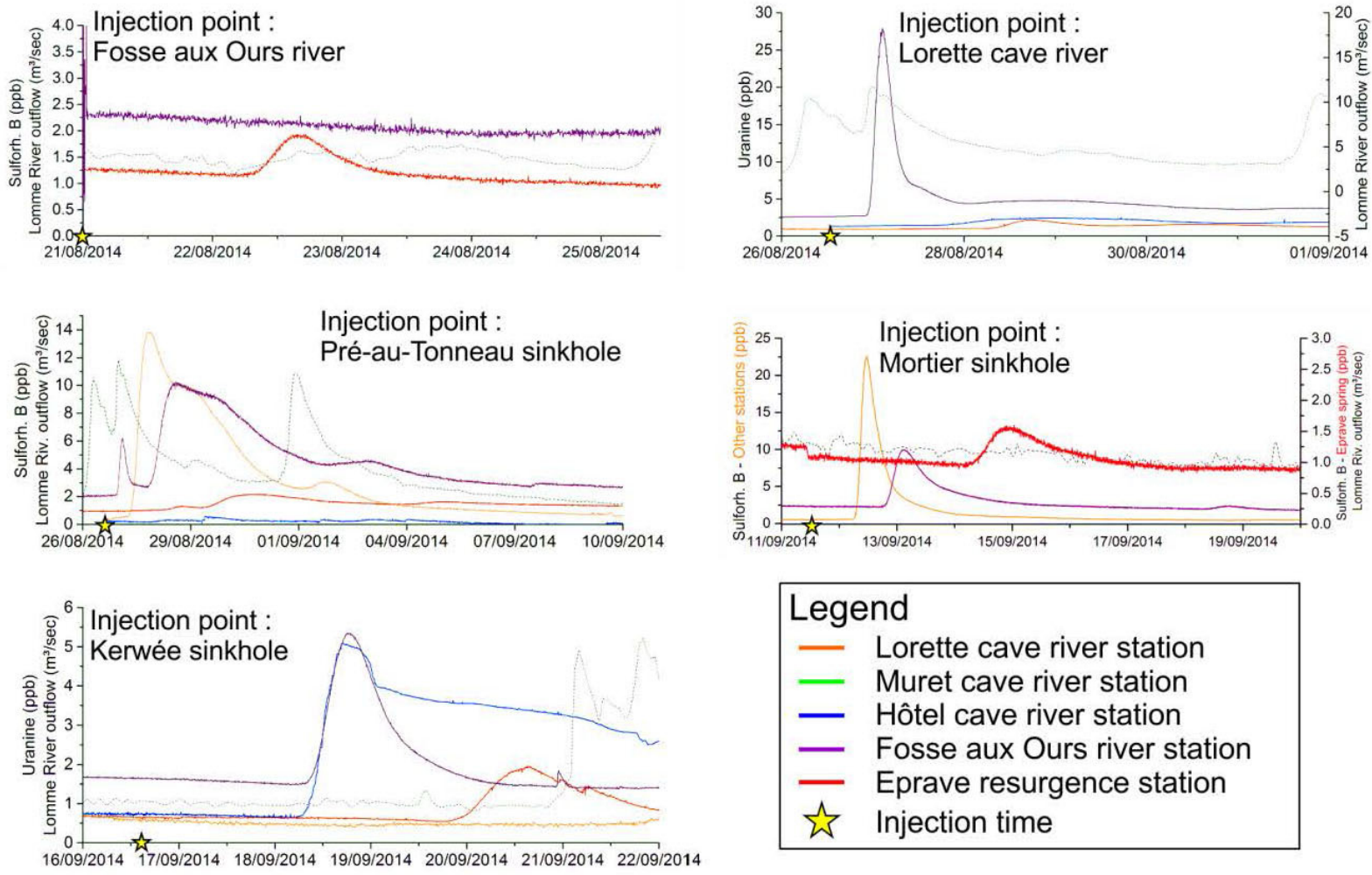

Figure 5. Breakthrough curves for the 9 tracer tests carried out in the LKS in February (High piezometric conditions) and September 2014 (Low piezometric conditions). Each graph represents one experiment showing the dye concentration at the downstream monitoring stations (one color for each station). The yellow star points the injection time. The dashed black line represents the surface Lomme River outflow in Rochefort and is representative to the general hydrological conditions. 
- The Lorette cave river (point 4 ; Figure 2);

- The Fosse aux Ours cave river (point 7);

- The Trouvée sinkhole (point 8).

Dye sampling was done at five points with field fluorometers:

- The river in the Lorette cave (point 4);

- The north rivers of Thiers des Falises :

- Hôtel cave river (point 5);

- Muret cave river (point 6);

- The south river of Thiers des Falizes :

- Fosse aux Ours river (point 7);

- The Eprave resurgence (point 10).

\section{Tracer Test Results}

The breakthrough curves for the 9 tracer tests experiments are presented in Figure 5 that also gives reference to the injection location and time. The outflow of the Lomme River is also given as it is representative to the hydrological conditions of the LKS.

Based on the tracer test results, the karst flow functioning within the LKS has been defined and appears to be much more complicated than expected. Indeed, the flow connections between underground rivers seem to vary with the hydrological conditions. Two cases were identified from our tracing results: one for high piezometric conditions, another for low piezometric conditions.

Figures 6 and 7 are two schematic maps illustrating the main hydrogeological connections of the LKS for both high and low piezometric conditions. Hydrodynamic characteristics (transit time, maximal speeds in meters/ hour) are indicated for each of the underground connection $(\longrightarrow)$.

\section{LKS Dynamic During High Piezometric Conditions}

Dye tracer injection from the Kerwée sinkhole demonstrates the connections with the northern underground rivers of the Thiers des Falizes area: the Hôtel and Muret caves (Figure 6). From those points, the underground river joins the southern river of Thiers des Falizes within the Fosse aux Ours cave. The north river of the Fosse aux Ours confluence is the underground Wamme River, flowing in the Fromelennes Formation with a high speed of more than 140 meters/hour.

Tracer injection inside the Mortier sinkhole highlights a connection with the Lorette cave river, as expected from previous studies (Delbrouck, 1974). This underground

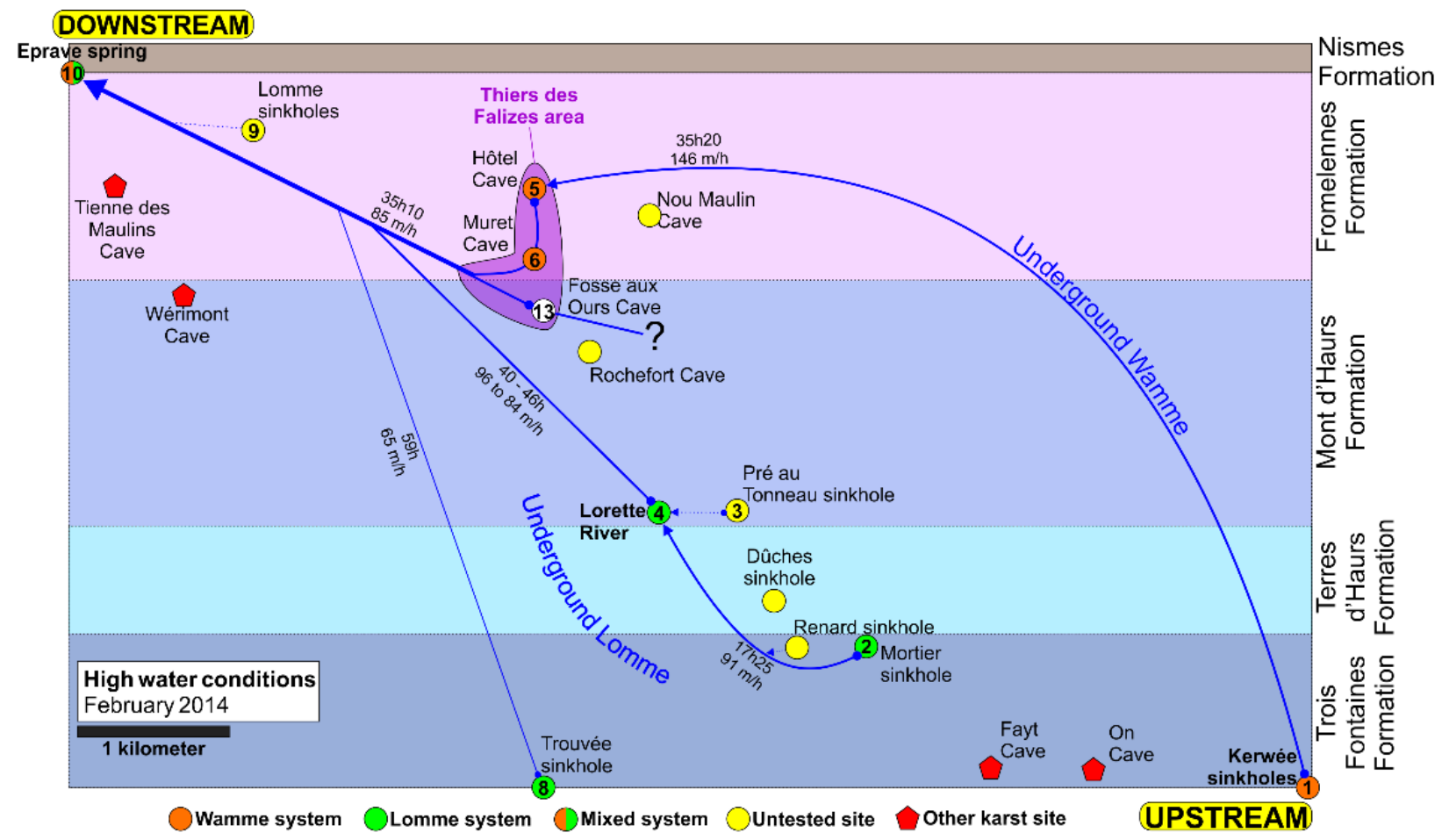

Figure 6. Schematic map of LKS dynamic during high piezometric conditions based on the tracer test campaign of February 2014. 


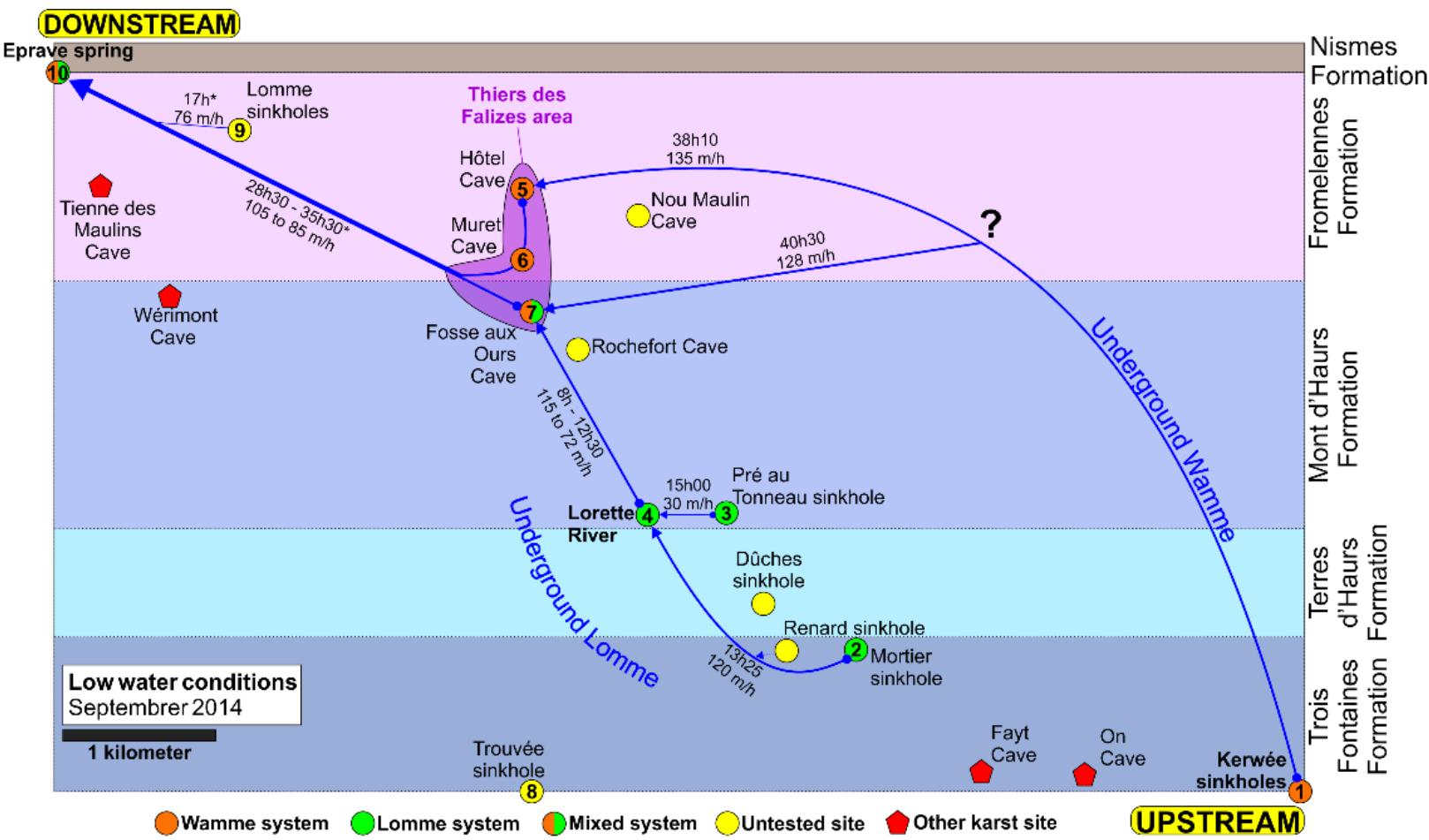

Figure 7. Schematic map of LKS dynamic during low piezometric conditions based on the tracer test campaign of September 2014 (*Meus \& Michel, 2011 ).

Lomme River continues toward the west and emerges after 40 hours at the Eprave resurgence. For these hydrological conditions, no evidence was found for a connection with the Thiers des Falizes area. During high piezometric condition, the underground Lomme seems to be drained by an adjacent system.

A last injection from the Trouvée sinkhole shows a connection with the Eprave spring in almost 60 hours. This little tributary system is also independent from the Thiers des Falizes area. The origin of the Fosse aux Ours river for high piezometric conditions is still unknown, further tracer test campaigns will be made in order to complete the high water condition scheme.

\section{LKS Dynamic During Low Piezometric Conditions}

The tracing during low piezometric conditions shows a very different organization of the flow paths inside the LKS, both for the Wamme and the Lomme systems (Figure 7).

Regarding the underground Wamme River, a very clear tracer signal was detected in the Thiers des Falizes area at the three monitoring stations (Hôtel, Muret and Fosse aux Ours rivers). Low piezometric conditions seem to connect the Wamme river with the southern river of this area, which was not the case during high piezometric conditions. The location of the diffluence of the Wamme river is still unknown (? on Figure 7).

As for the underground Lomme, a connection was proved between the Pré-au-Tonneau sinkhole and the Lorette cave river. The flow speeds are very slow (30 $\mathrm{m} / \mathrm{h}$ ) indicating a larger flow section, very different with the Mortier sinkhole - Lorette river connection.

From the latter, the water flows to the Fosse aux Ours cave in 8 to 13 hours, which means a maximal speed of 115 to $72 \mathrm{~m} / \mathrm{h}$. Flow conditions seems to be relatively identical to the previous section as shown by the BTC. At the Fosse aux Ours Cave, the underground Lomme meets the underground Wamme and the resulting river flows toward the Eprave resurgence.

\section{Conclusions and Perspectives}

The KARAG project aims to understand the dynamic of karst aquifers by using both geophysical and hydrogeological tools. For this purpose, the Lomme Karst System (Rochefort, Belgium) has been chosen and studied since 2013. One of the first objective of the 
project is to draw the hydrogeological behavior of this karst system: flow connections inside the karst system, reactions to various hydrological conditions, relations to the surface Lomme River. So far, 20 water probes have been installed within the LKS, providing high resolution data for further analysis. In 2014, 9 tracer tests using 5 GGUN-FL30 fluorometers were conducted, leading to a better understanding of the LKS dynamics. Two main underground rivers were identified but the results also highlight the variability of the karst hydraulic connections as aquifer water level conditions change.

Further work will be focused on the probes data: piezometric levels to define the aquifer dynamic, temperature, electrical conductivity recording and chemical analysis. All this information together with the tracer test results will help us to build a complete conceptual model for the LKS. Finally, the hydrological data will be used in addition to geophysical tools (ERT, gravimetry) in order to evaluate the capability of such techniques to measure karst and epikarst aquifer dynamics.

\section{References}

Barchy L, Dejonghe L, Marion JM. Submitted.

Rochefort - Nassogne 59/3-4. Carte géologique de Wallonie. Ed. Ministère de la Région Wallonne.

Blockmans S, Dumoulin V. Submitted. Houyet - Hansur-Lesse 59/1-2. Carte géologique de Wallonie. Ed. Ministère de la Région Wallonne.

Delbrouck R. 1974. Expérience de traçage des eaux souterraines de la Wamme et de la Lhomme. Ministère de l'Agriculture. Serv. Hydraulique Agricole, Distric V, Namur. 127p.

Meus P, Michel G. 2011. Quand la Lomme disparait. Eco Karst. N 85 (Septembre 2011). CWEPSS.

Schnegg P-A. 2002. An inexpensive field fluorometer for hydrogeological tracer tests with three tracers and turbidity measurement. Groundwater and Human development, Balkema, Mar del Plata, Argentina: p. 1484-1488.

SPW-DGO3. 2014. Etat des nappes d'eau souterraine de Wallonie. Edition : Service public de Wallonie, DGO 3 (DGARNE), Belgique. Dépôt légal D/2014/11802/11 - ISBN 978-2-8056-0142-2. 
